University of Wollongong

Research Online

Faculty of Social Sciences - Papers (Archive) Faculty of Arts, Social Sciences \& Humanities

2015

Powerful parenting and enabling contexts: lessons to support academic success

Amy Conley Wright

University of Wollongong, acwright@uow.edu.au

Follow this and additional works at: https://ro.uow.edu.au/sspapers

Part of the Education Commons, and the Social and Behavioral Sciences Commons

Research Online is the open access institutional repository for the University of Wollongong. For further information contact the UOW Library: research-pubs@uow.edu.au 


\title{
Powerful parenting and enabling contexts: lessons to support academic success
}

\author{
Abstract \\ Book review of: Social class and educational inequality: the impact of parents and schools, by Iram Siraj \\ and Aziza Mayo, Cambridge, UK, Cambridge University Press, 2014, 330 pp., £65 (hardback), ISBN \\ 9781107018051 \\ Keywords \\ enabling, academic, success, contexts, lessons, parenting, support, powerful \\ Disciplines \\ Education | Social and Behavioral Sciences \\ Publication Details \\ Wright, A. Conley. (2015). Powerful parenting and enabling contexts: lessons to support academic \\ success. Pedagogy Culture and Society, 23 (2), 323-329.
}




\section{REVIEW ESSAY}

\section{Powerful parenting and enabling contexts:}

Lessons to support academic success

Social class and educational inequality: the impact of parents and schools, by Iram Siraj \& Aziza Mayo, 2014, Cambridge, UK: Cambridge University Press, pp $£ 65.00$ (hardback), ISBN: 9781107018051

Amy Conley Wright

School of Health \& Society, University of Wollongong acwright@uow.edu.au

As an American recently relocated to Australia, mother to a toddler who is both an American and Australian citizen, I've been thinking a lot lately about how children's life chances are shaped by their social contexts. Like any parent, I want my child to have the best life possible, and I wonder where would be best to raise him. Both countries value giving people the opportunity to make the most of themselves: this is the American dream and the Australian 'fair go'. But a child's ability to succeed regardless of their parents' backgrounds is greater in Australia than the United States, where a parent's wages are far more likely to predict that of their children, according to a study of intergenerational social mobility across OECD countries. Government policies that support academic achievement make one of the biggest differences in social mobility (Causa and Johansson 2010). 
Why do some children succeed academically while others fail? How can we help more children fulfil their potential regardless of their backgrounds? These are the important questions explored by Iram Siraj and Aziza Mayo's new book, Social Class and Educational Inequality: The Impact of Parents and Schools. The book is underpinned by a rich set of case studies, backed up by quantitative data from the longitudinal Effective Pre-School, Primary and Secondary Education (EPPSE 3-16) study. EPPSE 3-16 followed over 3,000 children from the age of 3 until the end of their secondary schooling, to find whether children's home learning environment, education and other influences acted to promote or reduce inequality. Based on their profiles of risk and protective factors linked with school failure measured at age 3 , children's performance was predicted on national assessments in Maths and English for age 11, the end of primary school.

In most cases, socioeconomic status (SES) and early childhood experiences were found to predict school performance, but there were also children who did better or worse than expected based on their backgrounds. The case studies explicate and illustrate the factors that contributed to a child's academic success or vulnerability. This exploration yields significant insights into how academically successful and vulnerable children have been supported or not by their relationships and environments. The Bioecological Model of Human Development (Bronfenbrenner and Ceci 1994) was used to organize the research, which starts with the characteristics of the child and moves through the close environments and relationships that surround the child in the microsystem, with some discussion of more distal influences in the exoand macro-systems. Siraj and Mayo identify important influences and patterns of experiences that distinguish among children with different trajectories. In their analysis, Siraj and Mayo assumed children to be active agents in their own development, 
with their personal characteristics influencing the responses they receive and interactions they have with others.

The book is a great achievement of synthesis, bringing together the voices of the children and their parents and teachers with the quantitative data on their trajectories and findings from the broader literature. The authors comment "this particular kind of mixed-methods research not only combines extensive qualitative and quantitative data sets, but creates an iterative dialogue between the two types of methods, data and analysis to this extent is rare, if not unique" ( $\mathrm{p} 46$ ). Indeed. These data provide a significant opportunity to investigate the life trajectories of children and how their social contexts contribute to their academic outcomes. In the process, the authors relate their findings to the broader literature and find confirmation of some theories while extending others.

I read the book with two lenses: as a parent wanting to learn how to achieve success for my child and as a child advocate wondering what we can do for all children. In a world of growing inequality, parents want to do everything they can to make sure that their children can succeed academically and become part of the middle class that is shrinking in many rich nations (Hollinger, 2012). But an individualistic desire to concentrate resources into one's own child's success rather than spread resources around to support many children exacerbates inequality. Dewey (1900) recognized this when he said: "What the best and wisest parent wants for his child, that must we want for all the children of the community. Anything less is unlovely, and left unchecked, destroys our democracy" (p. 19). What can we learn about what the wisest parents (and teachers, schools, peers, communities and support networks) do, and how can we make sure all children get more of it? 


\section{Lessons for powerful parenting and enabling contexts}

Siraj and Mayo found that the academically successful case study children, from high and low SES backgrounds, had certain things in common. These commonalities related to their personal qualities as well as to aspects of their families, schools, support networks and peer relationships. The children deemed academically successful were found to have behavioural dispositions that helped them make the most of their experiences, including being persistent, motivated, aspirational, goal-orientated, and willing to ask for help from those around them. From different relationships and the experiences they offered, academically successful children typically received reinforcement and opportunities that helped them to develop self-regulation and a positive orientation to learning. Siraj and Mayo's study found that each of the major types of social environments and relationships that children experienced made distinct contributions to their capacities for academic success, but had shared qualities of emotional and practical support.

Schools offered meaningful learning experiences as well as important relationships with teachers and peers. All case study children doing well academically reported positive relationships with at least some teachers. Children characterised these teachers as holding them to high standards while making learning enjoyable and responding to their individual needs. The teachers whom they describe in positive terms had shared characteristics of an authoritative teaching style, enthusiasm for the subject, skilled classroom management and a friendly and approachable demeanour. Children reported enjoying learning and also retaining information best with the use of interactive teaching methods like attending the theatre and learning games.

Teachers also played an important role in making referrals for remediation or offering more challenging work when needed. Some case study children who ultimately 
went on to succeed academically needed early intervention to address academic or behavioural issues. While high SES families were reported as able to privately organize help, low SES families were reported as having to rely on school resources for remediation. Schools of children succeeding against the odds were more likely to offer additional learning resources, including booster classes in core subjects like Maths and English in primary school or afterschool classes and mentors in secondary school. Children reported that remedial help made them feel supported and increased their motivation to excel academically.

Children reported that connections with peers, especially friends, helped them to enjoy school. Children, parents and teachers suggested that mixing with more academically successful peers provided positive examples and motivation to do well. Practical support was often mutual, with children reporting that teaching their peers helped them learn material better. Participation in extracurricular activities offered additional learning opportunities and relationships, with parents and children describing these experiences as building self-confidence and offering an chance to excel at something besides school. Siraj and Mayo suggest that the knowledge and connections to others that children gain through extracurricular activities could potentially contribute to building their social and cultural capital, a particular boon for disadvantaged children that could aid in their social mobility.

However, beyond what schools and other close contexts did, Siraj and Mayo found that it was parenting that had the most powerful and enduring impact on children's trajectories. What parents of children succeeding as predicted or against the odds seemed to do most was engage in mutually enjoyable learning experiences with their children, give them positive messages about themselves and their potential, and help them build and maintain relationships with 'significant others' who offered 
something beneficial to their children. Parents of academically successful children were found to perceive themselves as partially responsible for their children's learning, which motivated them to offered practical support as well as strong emotional support for their children to succeed without applying pressure. These parenting approaches appeared to encourage the development of self-efficacy, as children internalized messages about their own academic competence and learned to access resources to support their development from a network of relationships in the community and school.

Not surprisingly, Siraj and Mayo found that commonalities among children experiencing academic vulnerability were often the converse of what was happening with their successful peers. But the nuances were important if we are to understand how certain attitudes and behaviours come to be associated with school failure and feelings of alienation about education. For example, a common message that academically vulnerable children received from their parents and other key people in their lives was that their ability and motivation were predetermined and not likely to change. This perception seemed to result in parents and others doing less for children who did not show academic aptitude early on, and in children developing negative selfperceptions about themselves as learners and a sense of helplessness rather than the sense of agency displayed by academically successful children.

The pattern of social environments and relationships that academically vulnerable children experienced differed in key respects from those of their more academically successful peers. For example, parents reported less regular engagement in high quality and educationally oriented home learning activities and less enjoyment of such activities. Simultaneously, in school, teachers noted that academically vulnerable children appeared to experience a lack of or ineffective practical and 
emotional support from parents. The majority of children showing vulnerability were found to have had some experience of peers exerting a negative impact. This negative impact appeared to result from a lack of academically successful peer models, perceptions that applying oneself was not cool, or peers interfering with learning processes or stimulating problem behaviour. For the less successful children, Siraj and Mayo found that their involvement in extracurricular activities was often left to the child, with parents generally not encouraging them to keep going when they lost interest because the activity was regarded as something to enjoy rather than beneficial to development.

One message I took away from the book is the importance of remaining aspirational for children. For the children who succeeded against the odds, it was often due to parents and other people in their lives not giving up on them despite challenges. This was illustrated by the case of Steven, whose life experiences are described in detail in the book, from interviews with Steven, his mother and his teachers. His mother describes Steven as a challenging infant and toddler: barely sleeping, constantly crying, biting and slapping other children. She described how she sought advice on handling his behaviour, taking him to medical clinics and specialists, and at age 2 testing uncovered that he could barely hear and he received an operation to restore hearing. After that, his mother recollected that his behaviour improved and he began to develop speech. His mother and older sister reported reading to Steven and engaged him in conversation and learning activities in the home. Despite this, primary schooling got off to a rough start: Steven struggled academically and behaviourally and did not perform well on assessments at age 7. This triggered the school offering him a 9-week intervention, which helped him grasp some of the basics of Maths and English and turned around his academic performance and behaviours. After that, his mother 
described how he steadily improved through the rest of primary school, gaining confidence in himself as a learner and getting extra help from teachers or classmates when needed. Both Steven and his mother suggested that taking guitar and dance lessons also built his confidence and enjoyment of learning. Later, in secondary school, his teachers stated that he was among their brightest students and would have no trouble achieving his aim of attending a good university. From her son's early struggles and trying to get the help he needed, Steven's mother commented that she had learned some important lessons: to trust her own intuition and judgement, to speak up to authority figures and not just follow their judgement, and to take matters into her own hands when necessary. She had found agency and voice as her child's advocate.

\section{$\underline{\text { Helping all children succeed }}$}

My own research relates to child advocacy, at the micro and macro levels, and Siraj and Mayo's book has important implications for both forms of advocacy. Advocacy at a micro level seeks to improve the situation of a particular child, while advocacy at the macro level seeks to address a social problem confronting a group of children (Wright and Jaffe 2013). In parenting towards success, social context matters, but so does the parents' sense of agency. These factors come together in parents' ability and willingness to advocate for their children when there are issues in their micro environments. How parents understand their role and responsibilities as parents predicts their involvement in their children's education (Hoover-Dempsey and Sandler, 1997). Siraj \& Mayo's research suggests that helping parents see themselves as their children's advocates and developing the attitudes and skills that would enable them to speak out for their children's best interests could help children overcome the pitfalls that can potentially put them on a path of school failure rather than success. These orientations to parenting can be taught, and social programs can be developed to help 
parents learn how to offer child-centred emotional and practical support that helps children develop self-efficacy and self-regulation.

As Siraj and Mayo make clear, there is also much that teachers and schools can do to encourage children to reach high and help them get there. Schools can implement consistent mechanisms for detecting academic problems and intervening early. Educational policy can also focus on facilitating positive relationships, by recruiting high quality teachers and encouraging community of learning teaching practices that engage students in academically supporting their peers. Schools as well as communities can provide children with access to extracurricular activities that broaden their social and cultural capital. But there remains a bigger policy question and agenda for child advocates: How can societies counter rising inequality and declining social mobility to give every child the opportunity to succeed?

Aspirations for children need to be mirrored for the children in their important close environments but also enabled by the larger society. It's every parent's dream to see their children succeed and enjoy the prestige and security that goes with success. But societal inequality and lack of social mobility undermine aspirations. This is where the fear that children have little chance to succeed in an unequal society can take root. Where parents' income closely predict that of their offspring, as is the case in the United Kingdom and the United States (Causa and Johansson 2010), there is reinforcement for giving up on children--it defies logic to think that children will exceed their social backgrounds. It is remarkable when children succeed against the odds of inequality. And it is shameful that so many struggle and fail. For future educators and others preparing for careers working with children and their families, Social class and educational inequality: The impact of parents and schools offers meaningful lessons and 
examples of how to support children's academic success regardless of their backgrounds.

I highly recommend the book as a core text for students studying young people's lives in education, human development and other social sciences. The authors draw upon and integrate a mix of theories from fields including sociology, psychology and anthropology, for a truly cross-disciplinary examination of the links between social disadvantage and academic outcomes. The book serves as an excellent teaching tool for the application of major theories and concepts such as the Bioecological Model of Human Development (Bronfenbrenner and Ceci 1994), Rutter's (1987) construction of resilience and Baumrind's (1978) description of authoritative parenting style. With their larger sample and mixed data set, the authors challenge Laureau's (2003) influential theory of concerted cultivation among middle class families and achievement of natural growth by working class families, finding that low SES families in which children were succeeding against the odds practiced 'active cultivation' that facilitated their children's access to meaningful learning opportunities and significant others outside the home. By seeing how these concepts manifest in the case study children's experiences, the book gives future educators and other professionals a framework to understand rather than judge the needs and behaviors of children and families. Social class and educational inequality: The impact of parents and schools also encourages respect for the complexity of experience each child brings with them and inspires hope that we can all collectively support children to succeed in school and life. 


\section{$\underline{\text { References }}$}

Baumrind, Diana. 1978. Parental disciplinary patterns and social competence in children. Youth and Society, 9: 239-276.

Bronfenbrenner, Urie, and Stephen J. Ceci. 1994. Nature-nuture reconceptualized in developmental perspective: A bioecological model. Psychological review 101 (4): 568586.

Causa, Orsetta, and Asa Johansson. 2010. A family affair: Intergenerational social mobility across OECD countries. OECD Journal: Economic Studies.

http://www.oecd.org/eco/labour/49849281.pdf

Dewey, John. 1900. The school and society. Chicago: University of Chicago Press.

Hollinger, J. (2012). A hollowing middle class. OECD Observer.

http://www.oecdobserver.org/news/fullstory.php/aid/3675/A_hollowing_middle_clas s.html

Hoover-Dempsey, Kathleen V., and Howard M. Sandler. 1997. Why do parents become involved in their children's education? Review of educational research 67 (1): 3-42.

Lareau, Annette. 2011. Unequal childhoods: Class, race, and family life. Berkeley and Los Angeles: University of California Press, 2011.

Rutter, Michael. 1987. Psychosocial resilience and protective mechanisms. American Journal of Orthopsychiatry 57: 316-331.

Wright, Amy Conley, and Kenneth J. Jaffe. 2013. Six Steps to Successful Child Advocacy: Changing the World for Children. Thousand Oaks, CA: SAGE Publications. 